\title{
Impact of Verticutting on the Efficacy and Soil Activity of ALS-inhibiting Herbicides for Dallisgrass Control
}

\author{
Austin Brown
}

Department of Crop and Soil Sciences, University of Georgia, 3111 Miller Plant Science Building, Athens, GA 30602

\section{James Brosnan}

Department of Plant Sciences, University of Tennessee, 2505 EJ Chapman Drive, Knoxville, TN 37996

\section{Nicholas Basinger}

Department of Crop and Soil Sciences, University of Georgia, 3111 Miller Plant Science Building, Athens, GA 30602

\section{Wesley Porter \\ Department of Crop and Soil Sciences, University of Georgia, 2360 Rainwater Road, Tifton, GA 31793}

\section{Gerald Henry}

Department of Crop and Soil Sciences, University of Georgia, 3111 Miller Plant Science Building, Athens, GA 30602

Additional index words. adsorption, carrier volume, cultural practices, golf course, irrigation, mobility, soil profile, turfgrass, weed management

\begin{abstract}
Dallisgrass (Paspalum dilatatum Poir.) control with postemergence herbicides is inefficient and inconsistent from year to year. Control with acetolactate synthase (ALS)-inhibiting herbicides may be enhanced through root absorption, but herbicide movement through dense turfgrass canopies may be difficult. The objectives of this research were to evaluate the influence of verticutting on the postemergence control of dallisgrass and the presence of ALS-inhibiting herbicides within the soil profile. Long-term dallisgrass control [17 weeks after initial treatment (WAIT)] was enhanced in response to verticutting at one of two locations. This may be attributed to differences in turfgrass management (mowing height) before trial initiation that impacted dallisgrass carbohydrate content and herbicide absorption. However, dallisgrass control with certain herbicides was enhanced at the second location in response to verticutting at earlier rating dates. Thiencarbazone + foramsulfuron + halosulfuron (TFH) and trifloxysulfuron at $112 \mathrm{~g} \cdot \mathrm{ha}^{-1}$ a.i. and carrier volume of $1628 \mathrm{~L} \cdot \mathrm{ha}^{-1}$ (TRI High $\mathrm{CV}$ ) following mowing + verticutting resulted in the greatest long-term control 17 WAIT at one of two trial locations, $86 \%$ and $85 \%$, respectively. Greenhouse experiments confirmed that mowing + verticutting dallisgrass before treatment followed by irrigation led to an increase in herbicide presence within the soil profile, regardless of herbicide. Presence of TFH went from 6.4 to $8.2 \mathrm{~mm}$, trifloxysulfuron at $28 \mathrm{~g} \cdot \mathrm{ha}^{-1} \mathrm{a}$ a.i. and carrier volume of $407 \mathrm{~L} \cdot \mathrm{ha}^{-1}$ went from 6.7 to $8.5 \mathrm{~mm}$, and TRI High CV went from 8.6 to $11.8 \mathrm{~mm}$.
\end{abstract}

Dallisgrass (Paspalum dilatatum Poir.) is often used as a warm-season forage grass or roadside vegetation (Bryson and DeFelice,

Received for publication 26 Aug. 2021. Accepted for publication 18 Nov. 2021

Published online 17 January 2022.

We would like to thank Bob Cunningham, Superintendent, Pine Hills Golf Club and Gerald Spear, Superintendent, Deer Trail Country Club for the use of their facilities.

G.H. is the corresponding author. E-mail: gmhenry@ uga.edu.

This is an open access article distributed under the CC BY-NC-ND license (https://creativecommons. org/licenses/by-nc-nd/4.0/) lawns, golf courses, and athletic fields (McCarty, 2008).

Current chemical control options for dallisgrass in managed turfgrass systems are neither efficient nor consistent from year to year. Monosodium methanearsonate (MSMA) is a contact herbicide that results in significant canopy loss following sequential applications, but regrowth can occur throughout summer from rhizome carbohydrate reserves and concerns exist regarding phytotoxicity to desirable warm-season turfgrass species (Henry et al., 2007b, 2008; McCarty et al., 1991; Smith et al., 1974). Furthermore, numerous restrictions were placed on MSMA by an Environmental Protection Agency (EPA) ruling in 2009 that significantly limits its use for turfgrass applications (U.S. Environmental Protection Agency, 2009). Brosnan et al., (2010) reported $90 \%$ control of dallisgrass $76 \mathrm{~d}$ after treatment (DAT) with single, spring applications of fluazifop, but significant bermudagrass (Cynodon spp.) injury in response to this chemistry has also been reported (Bryson and Wills, 1985; Johnson, 1992; McElroy and Breeden, 2006). Greater than 95\% dallisgrass control was observed when pinoxaden, an acetyl coenzyme A carboxylase (ACCase) inhibitor, was applied

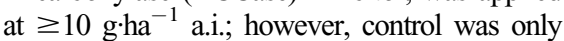
monitored for $35 \mathrm{~d}$ and research was conducted in a controlled environment (Peppers et al., 2020). Initial control $[1$ month after initial treatment (MAIT)] in response to foramsulfuron was $<60 \%$, but control declined to $<5 \% 1$ year after initial treatment (YAIT) (Henry et al., 2007b).

Research examining herbicide application timing for dallisgrass control revealed that early spring and fall treatments are most successful, but timing was herbicide specific. Elmore et al., (2013) observed better control with early spring fluazifop applications due to optimal translocation and susceptibility of dallisgrass at emergence from winter dormancy. Meanwhile, Johnston and Henry (2016) synchronized herbicide applications of thiencarbazone + foramsulfuron + halosulfuron (TFH) with fall movement of carbohydrates to rhizome tissue before the onset of dormancy to maximize long-term dallisgrass control (Davis et al., 1978; Smith et al., 1993). Unfortunately, spring applications of fluazifop could result in nontarget damage to hybrid bermudagrass [Cynodon dactylon (L.) Pers. $\times$ C. transvaalensis Burtt Davy], while delaying TFH applications to fall promotes dallisgrass disruption of turfgrass aesthetics and playability all summer, thus warranting investigation into methods that improve herbicide efficacy during summer months.

Acetolactate synthase (ALS)-inhibiting herbicide activity may be enhanced through root absorption of target weeds, but herbicide movement through dense turfgrass canopies and into the root zone may be difficult (Lycan and Hart, 2006; Williams et al., 2003). Utilization of higher carrier volumes or irrigation following application could increase herbicide movement through the soil profile, while cultivation techniques may enhance herbicide absorption through wounded rhizome tissue. 
Beckie and McKercher (1990) and Starrett et al. (2000) detected greater concentrations of herbicides deeper in the soil profile when applications were followed by irrigation events. Richardson et al. (2020) observed excellent control of hybrid bermudagrass when herbicide applications followed fraise mowing, a mechanical cultivation technique designed to remove the turfgrass canopy and lacerate rhizome meristems. Verticutting is a common cultivation practice that uses vertically oriented blades to remove thatch, sever stolons, and expose rhizomes (Turgeon, 2011), potentially wounding them in the process. Coordinating herbicide applications with verticutting events may provide earlier options for dallisgrass control since these cultivation practices are typically conducted several times during the summer. The combination of higher carrier volumes or irrigation with plant wounding may increase the efficacy of ALS-inhibiting herbicides for dallisgrass control through enhanced herbicide root zone deposition and rhizome absorption. Therefore, the objectives of this research were to evaluate the impact of verticutting on the control of dallisgrass and presence of ALS-inhibiting herbicides within the soil profile.

\section{Materials and Methods}

Field experiments. Trials were conducted during the summer and fall of 2020 at Pine Hills Golf Club $(\mathrm{PH})$ in Winder, GA (lat. $33.97^{\circ} \mathrm{N}$, long. $83.69^{\circ} \mathrm{W}$ ) and Deer Trail Country Club (DT) in Commerce, GA (lat. $34.11^{\circ} \mathrm{N}$, long. $83.28^{\circ} \mathrm{W}$ ). The soil at $\mathrm{PH}$ was a Madison sandy clay loam (fine, kaolinitic, thermic Typic Kanhapludults), while the soil at DT was a Cecil sandy clay loam (fine, kaolinitic, thermic Typic Kanhapludults). Research was performed on mature ( $>5$ years) dallisgrass infestations present in a common bermudagrass [Cynodon dactylon (L.) Pers.] rough mowed at $5.1 \mathrm{~cm}$ at PH and a 'Tifway 419' hybrid bermudagrass fairway mowed at $2.5 \mathrm{~cm}$ at DT. The experimental design was an incomplete split-block with cultivation practice (mowing alone and mowing + verticutting) as the main blocks and herbicide treatment as the sub-plots arranged in a randomized complete block design within each cultivation practice block with four replications. The entire trial site at each location was mowed to a height of 2.5 $\mathrm{cm}$ with a rotary mower. Therefore, the $\mathrm{PH}$ site was scalped to a height of $2.5 \mathrm{~cm}$, whereas the DT site was mowed at its current height. Immediately following mowing, the cultivation treatment block was verticut in one direction to a depth of $1.9 \mathrm{~cm}$ using a CR550HC Compact Power Rake (Billy Goat Industries, Lee's Summit, MO) equipped with $10 \mathrm{~cm}$ flail blades spaced $1.7 \mathrm{~cm}$ apart. Debris was removed through hand raking at each location. Mowing (height of $2.5 \mathrm{~cm}$ ) and verticutting (depth of $1.9 \mathrm{~cm}$ ) were conducted a second time (same direction as previously conducted) on the same day as sequential herbicide applications. Both mowing and verticutting events at each location were conducted $\approx 30 \mathrm{~min}$ before herbicide application. Each experimental area was mowed weekly during the trial duration with turfgrass clippings returned to the canopy. Rainfall was the only source of water at both locations.

Herbicide treatments included a nontreated check, MSMA (MSMA 6.6 L; Drexel Chemical Co., Memphis, TN) at $2500 \mathrm{~g} \cdot \mathrm{ha}^{-1}$ a.i., trifloxysulfuron (Monument; Syngenta Crop Protection, LLC, Greensboro, NC) at 28 and $112 \mathrm{~g} \cdot \mathrm{ha}^{-1}$ a.i. (trifloxysulfuron yearly maximum is $119 \mathrm{~g} \cdot \mathrm{ha}^{-1}$ a.i.), and TFH (Tribute Total; Bayer CropScience, Research Triangle Park, NC) at $137 \mathrm{~g} \cdot \mathrm{ha}^{-1}$ a.i. (Table 1). Herbicides were selected based on previously documented activity on perennial grass weed control. Trifloxysulfuron treatments included a nonionic surfactant (Induce; Helena Chemical Co., Collierville, TN) at $0.25 \%(\mathrm{v} / \mathrm{v})$, whereas the TFH treatments were applied with a methylated seed oil surfactant (Dyne-Amic, Helena Chemical Co.) at $0.5 \%(\mathrm{v} / \mathrm{v})$ and ammonium sulfate (SigmaAldrich, St. Louis, MO) at $1.7 \mathrm{~kg} \cdot \mathrm{ha}^{-1}$. Initial treatments were applied to plots $(1.5 \mathrm{~m} \times 1.5$ $\mathrm{m})$ on 5 June 2020 at both locations with a $\mathrm{CO}_{2}$-pressured backpack sprayer equipped with two XR8004VS nozzle tips (Teejet; Spraying Systems Co., Wheaton, IL) calibrated to deliver 407 or $1628 \mathrm{~L} \cdot \mathrm{ha}^{-1}$ at 221 $\mathrm{kPa}$. A sequential application was made 4week later (10 July 2020) using identical rates and carrier volumes. The trifloxysulfuron treatment at $112 \mathrm{~g} \cdot \mathrm{ha}^{-1}$ a.i. at a carrier volume of $1628 \mathrm{~L} \cdot \mathrm{ha}^{-1}$ (TRI High CV) was added to evaluate the effect of a high carrier volume on dallisgrass control. The ratio of trifloxysulfuron active ingredient to water carrier volume remained constant between both trifloxysulfuron treatments. Previous research evaluating fixed active ingredient amounts in conjunction with increasing water carrier volume did not improve weed control, because higher carrier volumes diluted the spray solution (Knoche, 1994; Shaw et al., 2000). However, it is important to note that the sequential application of trifloxysulfuron at $112 \mathrm{~g} \cdot \mathrm{ha}^{-1}$ a.i. exceeded the yearly maximum of $119 \mathrm{~g} \cdot \mathrm{ha}^{-1}$ a.i.

Table 1. Field experiment treatments evaluating dallisgrass control at Pine Hills Golf Club in Winder, GA and Deer Trail Country Club in Commerce, GA.

Herbicide treatment

\begin{tabular}{|c|c|c|c|c|}
\hline Common name & Trade name & Verticut $^{\mathrm{z}}$ & Rate (g.ha ${ }^{-1}$ a.i.) & Carrier vol $\left(\mathrm{L} \cdot \mathrm{ha}^{-1}\right)$ \\
\hline MSMA $^{y}$ & MSMA & No & 2500 & 407 \\
\hline $\mathrm{TFH}^{\mathrm{x}}$ & Tribute total & No & 137 & 407 \\
\hline Trifloxysulfuron & Monument & No & 28 & 407 \\
\hline Trifloxysulfuron & Monument & No & $112^{\mathrm{w}}$ & 1628 \\
\hline MSMA & MSMA & Yes & 2500 & 407 \\
\hline TFH & Tribute total & Yes & 137 & 407 \\
\hline Trifloxysulfuron & Monument & Yes & 28 & 407 \\
\hline Trifloxysulfuron & Monument & Yes & 112 & 1628 \\
\hline
\end{tabular}

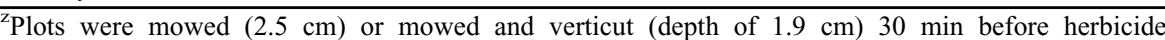
application.

${ }^{\mathrm{y}}$ MSMA $=$ monosodium methanearsonate; TFH $=$ thiencarbazone + foramsulfuron + halosulfuron.

${ }^{\mathrm{x}} \mathrm{TFH}$ was applied with a methylated seed oil surfactant at $0.5 \%(\mathrm{v} / \mathrm{v})$ and ammonium sulfate at 1.7 $\mathrm{kg} \cdot \mathrm{ha}^{-1}$. Trifloxysulfuron was applied with a nonionic surfactant at $0.25 \%(\mathrm{v} / \mathrm{v})$. Treatments were applied on 5 June 2020 with a sequential applied on 10 July 2020

${ }^{\mathrm{w}}$ The sequential application of trifloxysulfuron at $112 \mathrm{~g} \cdot \mathrm{ha}^{-1}$ a.i. exceeded the yearly maximum of $119 \mathrm{~g} \cdot \mathrm{ha}^{-1}$ a.i. 
Table 2. Greenhouse experiment treatments evaluating herbicide movement through soil columns at the Athens Turfgrass Research and Education Center in Athens, GA.

Herbicide treatment

\begin{tabular}{|c|c|c|c|c|c|}
\hline Common name & Trade name & Rate (g.ha ${ }^{-1}$ a.i.) & Carrier vol $\left(\mathrm{L} \cdot \mathrm{ha}^{-1}\right)$ & Irrigation $^{\mathrm{z}}(\mathrm{mm})$ & Verticut $^{\mathrm{y}}$ \\
\hline $\mathrm{TFH}^{\mathrm{x}}$ & Tribute total & 137 & 407 & 0 & No \\
\hline Trifloxysulfuron $^{\mathrm{w}}$ & Monument & 28 & 407 & 0 & No \\
\hline Trifloxysulfuron & Monument & 112 & 1628 & 0 & No \\
\hline TFH & Tribute total & 137 & 407 & 0 & Yes \\
\hline Trifloxysulfuron & Monument & 28 & 407 & 0 & Yes \\
\hline Trifloxysulfuron & Monument & 112 & 1628 & 0 & Yes \\
\hline TFH & Tribute total & 137 & 407 & 12.8 & No \\
\hline Trifloxysulfuron & Monument & 28 & 407 & 12.8 & No \\
\hline Trifloxysulfuron & Monument & 112 & 1628 & 12.8 & No \\
\hline TFH & Tribute total & 137 & 407 & 12.8 & Yes \\
\hline Trifloxysulfuron & Monument & 28 & 407 & 12.8 & Yes \\
\hline Trifloxysulfuron & Monument & 112 & 1628 & 12.8 & Yes \\
\hline
\end{tabular}

${ }^{\mathrm{z}}$ Irrigation $(6.4 \mathrm{~mm})$ was applied 24 and $72 \mathrm{~h}$ after herbicide treatments for a total of $12.8 \mathrm{~mm}$.

${ }^{\mathrm{y}}$ Plots were mowed $(2.5 \mathrm{~cm})$ or mowed and verticut (depth of $\left.1.9 \mathrm{~cm}\right) 30$ min before herbicide application.

${ }^{\mathrm{x}_{\mathrm{TFH}}}=$ thiencarbazone + foramsulfuron + halosulfuron

${ }^{\mathrm{w}}$ Trifloxysulfuron was applied with a nonionic surfactant at $0.25 \%(\mathrm{v} / \mathrm{v})$. TFH was applied with a methylated seed oil surfactant at $0.5 \%(\mathrm{v} / \mathrm{v})$ and ammonium sulfate at $1.7 \mathrm{~kg} \cdot \mathrm{ha}^{-1}$.

wide) to a depth of $12.7 \mathrm{~cm}$. Cores were removed from nonirrigated plots $2 \mathrm{~h}$ after herbicide application, while cores were removed from irrigated plots $2 \mathrm{~h}$ after the second irrigation event. Cores were cut in half vertically using a $38-\mathrm{cm}$ table saw to yield two identical cross sections of the soil profile. Soil cores were placed in trays with the flat side pointing upward. Two rows of annual ryegrass (Lolium multiflorum L.) seed were placed side by side ( $1 \mathrm{~cm}$ apart) down the center of each core half and gently pressed into the soil with tweezers to increase seed to soil contact and avoid excessive soil disturbance. Annual ryegrass was selected to determine the presence of each herbicide within the soil profile due to sensitivity to ALS-inhibiting herbicides and an accelerated germination rate. Seeded cores were placed in the greenhouse and monitored for ryegrass germination. Pots were watered using an overhead irrigation system calibrated to deliver $3.8 \mathrm{~cm}$ water/week. Natural light was supplemented with artificial light (metal halide) to remain at $500 \mu \mathrm{mol} \cdot \mathrm{m}^{-2} \cdot \mathrm{s}^{-1}$ photosynthetic photon flux (measured at the canopy) in a 12-h day to approximate summer light intensity and photoperiod. Conditions in the climate-controlled greenhouse were maintained at day/night temperatures of $32 / 26^{\circ} \mathrm{C}$. Experimental blocks were arranged along a gradient created by the greenhouse cooling pads and associated fans. Experimental runs were conducted simultaneously in separate greenhouses.

Data collection and analysis. Percent dallisgrass cover was evaluated visually 4,8 , and 12 weeks after initial treatment (WAIT) for field experiments. Initial dallisgrass cover was $50 \%$ to $90 \%$ before the start of the trials. Percent dallisgrass control for each treatment was calculated by comparing cover at each rating time relative to dallisgrass cover at time of initial herbicide application within each replication and experimental run using the following equation:

$$
\% C=[(I-T) / I] \times 100
$$

where $C$ is the control, $I$ is the dallisgrass cover at the time of initial herbicide application, and $T$ is the dallisgrass cover at the respective rating date in the treated plot. Percentage of control used a scale of $0 \%$ to $100 \%$, where 0 was no dallisgrass control, and $100 \%$ was complete dallisgrass control. Grid counts were conducted to assess dallisgrass cover 17 WAIT. A $0.3-\mathrm{m}^{2}$ grid with 2.5 $\mathrm{cm} \times 2.5 \mathrm{~cm}$ intersect spacing was randomly placed within each plot. The following equation was used to convert grid counts to percent cover:

$$
(a / b) \times 100=c
$$

where $a$ is the number of intersects where dallisgrass was present, $b$ is the total number of intersections (25), and $c$ is the percent dallisgrass (Richardson et al., 2001).

Annual ryegrass seed germination was monitored for 2 weeks in the greenhouse. A ruler was used to determine the depth of the soil profile $(\mathrm{mm})$ that annual ryegrass germination was impacted by the presence of trifloxysulfuron or TFH (visual plant necrosis or stunted growth). Depth of activity for each of the two seeded rows along the surface of each soil core half were averaged together. Therefore, two depth of herbicide presence data points were generated for each treatment.

Analysis was conducted separately for 4, 8 , and 12 WAIT rating dates for visual dallisgrass control, control 17 WAIT based on grid counts, and soil depth of herbicide presence to make comparisons only within each rating event. Data were arcsine square-root transformed to stabilize variance as described by Bowley (2008) before being subjected to analysis of variance in SAS (SAS v. 9.2; SAS Institute Inc., Cary, NC) using error partitioning appropriate for an incomplete splitblock analysis and an incomplete split-splitblock analysis in the mixed models procedure. Interpretations were not different from nontransformed data; therefore, nontransformed means are presented for clarity. All data were subjected to analysis of covariance in SAS using the appropriate expected mean square values described by Federer and Meredith (1992). Treatment means were separated using Fisher's protected least significant difference test at $\alpha=0.05$.

\section{Results and Discussion}

Field experiments. Experimental run-bytreatment interactions for field trials were significant for dallisgrass control data $(\mathrm{F}=$ $10.91, P=0.008)$. Therefore, data were not pooled across experimental runs and results for each location will be presented separately. A significant interaction between cultural practice and herbicide treatment was observed for dallisgrass control at $\mathrm{PH}(\mathrm{F}=$ 86.50, $P<0.0001)$ and DT $(\mathrm{F}=90.30, P<$ 0.0001 ) (Tables 3 and 4).

Pine Hills. Mowing + verticutting before herbicide application significantly increased dallisgrass control 4 WAIT for the nontreated check, TFH, and trifloxysulfuron at the low carrier volume $\left(407 \mathrm{~L} \cdot \mathrm{ha}^{-1}\right)$ and low rate $(28$ g.ha ${ }^{-1}$ a.i.) (TRI Low CV) compared with those same treatments following mowing alone (Table 3). Although control was minimal, mowing + verticutting resulted in $16 \%$ dallisgrass control while mowing alone provided no control. The greatest amount of control 4 WAIT was observed in response to TFH (86\%) and TRI High CV (83\%) following mowing + verticutting. Dallisgrass control with MSMA (66\% to $67 \%$ ) 4 WAIT was unaffected by cultural practices. Contact herbicides like MSMA often require the presence of foliage at application for maximum deposition and subsequent weed control (Currier and Dybing, 1959). However, the mowing and mowing + verticutting MSMA treatments resulted in similar dallisgrass control 4 WAIT at PH.

Control increased for all treatments 8 WAIT (Table 3). Mowing + verticutting further increased control to $30 \%$ for the nontreated check while mowing alone did not control dallisgrass. The greatest level of control 8 WAIT was observed in response to TFH (94\%), TRI High CV (91\%), and MSMA $(90 \%)$ following mowing + verticutting as well as TFH following mowing (84\%). Henry et al. (2019) observed similar control (94\%) of common carpetgrass [Axonopus fissifolius (Raddi) Kuhlm.], a perennial warm-season grass weed, in response to sequential applications of MSMA at 2200 $\mathrm{g} \cdot \mathrm{ha}^{-1}$ a.i. Dallisgrass control 8 WAIT was increased for TFH, TRI Low CV, and TRI High CV treatments in response to mowing + verticutting compared with those same treatments following mowing alone.

By 12 WAIT, dallisgrass began to recover and control was reduced in all treatments, regardless of cultural practice (Table 3 ). The addition of mowing + verticutting significantly increased control of the nontreated check, TFH, TRI Low CV, and TRI High CV 12 WAIT compared with those same treatments following mowing alone. The highest level of control 12 WAIT was observed in 
Table 3. Impact of cultural practices and herbicide treatment on dallisgrass (Paspalum dilatatum Poir.) control at Pine Hills Golf Club in Winder, GA during Summer and Fall 2020.

\begin{tabular}{|c|c|c|c|c|c|}
\hline & & $4 \mathrm{WAIT}^{\mathrm{z}}$ & 8 WAIT & 12 WAIT & 17 WAIT \\
\hline Herbicide treatment ${ }^{\mathrm{y}}$ & Cultural practice ${ }^{\mathrm{x}}$ & \multicolumn{4}{|c|}{ Dallisgrass control $^{\mathrm{w}}(\%)$} \\
\hline Nontreated check & Mowing & $0 \mathrm{e}^{\mathrm{v}}$ & $0 \mathrm{f}$ & $0 \mathrm{~d}$ & $0 \mathrm{e}$ \\
\hline MSMA & Mowing & $67 \mathrm{~b}$ & $80 \mathrm{~b}$ & $72 \mathrm{~b}$ & $52 \mathrm{c}$ \\
\hline TFH & Mowing & $60 \mathrm{~b}$ & $84 \mathrm{ab}$ & $69 \mathrm{~b}$ & $55 \mathrm{c}$ \\
\hline TRI Low CV & Mowing & $20 \mathrm{~d}$ & $17 \mathrm{e}$ & $8 \mathrm{~d}$ & 8 e \\
\hline TRI High $\mathrm{CV}^{\mathrm{u}}$ & Mowing & $72 \mathrm{ab}$ & $79 \mathrm{~b}$ & $74 \mathrm{~b}$ & $61 \mathrm{c}$ \\
\hline Nontreated check & Mowing + verticutting & $16 \mathrm{~d}$ & $30 \mathrm{~d}$ & $10 \mathrm{~d}$ & $5 \mathrm{e}$ \\
\hline MSMA & Mowing + verticutting & $66 \mathrm{~b}$ & $90 \mathrm{ab}$ & $77 \mathrm{ab}$ & $73 \mathrm{~b}$ \\
\hline TFH & Mowing + verticutting & $86 \mathrm{a}$ & $94 \mathrm{a}$ & $87 \mathrm{a}$ & $86 \mathrm{a}$ \\
\hline TRI Low CV & Mowing + verticutting & $41 \mathrm{c}$ & $65 \mathrm{c}$ & $36 \mathrm{c}$ & $27 \mathrm{~d}$ \\
\hline TRI High CV & Mowing + verticutting & $83 \mathrm{ab}$ & $91 \mathrm{a}$ & $87 \mathrm{a}$ & $85 \mathrm{a}$ \\
\hline $\operatorname{LSD}_{(0.05)}$ & & 12 & 10 & 10 & 11 \\
\hline
\end{tabular}

${ }^{\mathrm{z}} \mathrm{WAIT}=$ weeks after initial treatment; MSMA $=$ monosodium methanearsonate; $\mathrm{TFH}=$ thiencarbazone + foramsulfuron + halosulfuron; TRI Low $\mathrm{CV}=$ trifloxysulfuron low carrier volume + low herbicide rate; TRI High CV $=$ trifloxysulfuron high carrier volume + high herbicide rate; $\operatorname{LSD}_{(0.05)}=$ least significant difference at $P \leq 0.05$.

${ }^{\mathrm{y}}$ MSMA was applied at $2.5 \mathrm{~kg} \cdot \mathrm{ha}^{-1}$ a.i.; TFH was applied at $137 \mathrm{~g} \cdot \mathrm{ha}^{-1}$ a.i.; trifloxysulfuron was applied at $28 \mathrm{~g} \cdot \mathrm{ha}^{-1}$ a.i. at $407 \mathrm{~L} \cdot \mathrm{ha}^{-1}$ (Low CV) and $112 \mathrm{~g} \cdot \mathrm{ha}^{-1}$ a.i. at $1628 \mathrm{~L} \cdot \mathrm{ha}^{-1}$ (High CV). TFH was applied with a methylated seed oil surfactant at $0.5 \%(\mathrm{v} / \mathrm{v})$ and ammonium sulfate at 1.7 $\mathrm{kg} \cdot \mathrm{ha}^{-1}$. Trifloxysulfuron was applied with a nonionic surfactant at $0.25 \%(\mathrm{v} / \mathrm{v})$. Treatments were applied on 5 June 2020 with a sequential applied on 10 July 2020.

${ }^{\mathrm{x}}$ Plots were mowed $(2.5 \mathrm{~cm})$ or mowed and verticut (depth of $1.9 \mathrm{~cm}$ ) before herbicide application.

${ }^{\mathrm{w}}$ Control at 4, 8, and 12 WAIT were visually assessed while control at 17 WAIT was determined through grid counts (25 intersecting points).

${ }^{v}$ Means within a column followed by the same lowercase letter are not significantly different at $P \leq$ 0.05 according to Fisher's Protected LSD test.

${ }^{\mathrm{u}}$ The sequential application of trifloxysulfuron at $112 \mathrm{~g} \cdot \mathrm{ha}^{-1}$ a.i. exceeded the yearly maximum of $119 \mathrm{~g} \cdot \mathrm{ha}^{-1}$ a.i.

response to TFH (87\%), TRI High CV (87\%), and MSMA (77\%) following mowing + verticutting. Johnston and Henry (2016) observed less dallisgrass control (65\%) 10 WAIT in response to sequential applications of TFH at $137 \mathrm{~g} \cdot \mathrm{ha}^{-1}$ a.i. when plants were

mowed at $3.8 \mathrm{~cm}$. Sequential applications (1 week apart) of MSMA at $1250 \mathrm{~g} \cdot \mathrm{ha}^{-1}$ a.i. only resulted in $22 \%$ dallisgrass control 3 MAIT (Henry et al., 2007b). At 17 WAIT, all treatments exhibited higher dallisgrass control when applied after mowing + verticutting

Table 4. Impact of cultural practices and herbicide treatment on dallisgrass (Paspalum dilatatum Poir.) control at Deer Trail Country Club in Commerce, GA during Summer and Fall 2020.

\begin{tabular}{|c|c|c|c|c|c|}
\hline & & $4 \mathrm{WAIT}^{\mathrm{z}}$ & 8 WAIT & 12 WAIT & 17 WAIT \\
\hline Herbicide treatment ${ }^{\mathrm{y}}$ & Cultural practice $^{\mathrm{x}}$ & \multicolumn{4}{|c|}{ Dallisgrass control $^{\mathrm{w}}(\%)$} \\
\hline Nontreated Check & Mowing & $0 \mathrm{~d}^{\mathrm{V}}$ & $0 \mathrm{e}$ & $0 \mathrm{e}$ & $2 d$ \\
\hline MSMA & Mowing & $33 \mathrm{c}$ & $91 \mathrm{a}$ & $93 \mathrm{ab}$ & $94 \mathrm{ab}$ \\
\hline TFH & Mowing & $73 \mathrm{a}$ & $93 \mathrm{a}$ & $96 \mathrm{a}$ & $92 \mathrm{ab}$ \\
\hline TRI Low CV & Mowing & $6 \mathrm{~d}$ & $48 \mathrm{c}$ & $33 \mathrm{~d}$ & $19 \mathrm{c}$ \\
\hline TRI High $\mathrm{CV}^{\mathrm{u}}$ & Mowing & $81 \mathrm{a}$ & $90 \mathrm{a}$ & $97 \mathrm{a}$ & $98 \mathrm{a}$ \\
\hline Nontreated Check & Mowing + verticutting & $9 \mathrm{~d}$ & $21 \mathrm{~d}$ & $3 \mathrm{e}$ & $1 \mathrm{~d}$ \\
\hline MSMA & Mowing + verticutting & $79 \mathrm{a}$ & $93 \mathrm{a}$ & $89 \mathrm{ab}$ & $93 \mathrm{ab}$ \\
\hline $\mathrm{TFH}$ & Mowing + verticutting & $71 \mathrm{a}$ & $89 \mathrm{a}$ & $91 \mathrm{ab}$ & $89 \mathrm{a}$ \\
\hline TRI Low CV & Mowing + verticutting & $58 \mathrm{~b}$ & $73 \mathrm{~b}$ & $51 \mathrm{c}$ & $27 \mathrm{c}$ \\
\hline TRI High CV & Mowing + verticutting & $78 \mathrm{a}$ & $91 \mathrm{a}$ & $80 \mathrm{~b}$ & $80 \mathrm{~b}$ \\
\hline $\operatorname{LSD}_{(0.05)}$ & - & 11 & 9 & 13 & 14 \\
\hline
\end{tabular}

${ }^{\mathrm{z}} \mathrm{WAIT}=$ weeks after initial treatment; MSMA $=$ monosodium methanearsonate; $\mathrm{TFH}=$ thiencarbazone + foramsulfuron + halosulfuron; TRI Low CV $=$ trifloxysulfuron low carrier volume + low herbicide rate; TRI High CV $=$ trifloxysulfuron high carrier volume + high herbicide rate; $\operatorname{LSD}_{(0.05)}=$ least significant difference at $P \leq 0.05$.

${ }^{\mathrm{y}}$ MSMA was applied at $2.5 \mathrm{~kg} \cdot \mathrm{ha}^{-1}$ a.i.; TFH was applied at $137 \mathrm{~g} \cdot \mathrm{ha}^{-1}$ a.i.; trifloxysulfuron was applied at $28 \mathrm{~g} \cdot \mathrm{ha}^{-1}$ a.i. at $407 \mathrm{~L} \cdot \mathrm{ha}^{-1}$ (Low CV) and $112 \mathrm{~g} \cdot \mathrm{ha}^{-1}$ a.i. at $1628 \mathrm{~L}^{-1} \mathrm{ha}^{-1}$ (High CV). TFH was applied with a methylated seed oil surfactant at $0.5 \%(\mathrm{v} / \mathrm{v})$ and ammonium sulfate at 1.7 $\mathrm{kg} \cdot \mathrm{ha}^{-1}$. Trifloxysulfuron was applied with a nonionic surfactant at $0.25 \%(\mathrm{v} / \mathrm{v})$. Treatments were applied on 5 June 2020 with a sequential applied on 10 July 2020.

${ }^{x}$ Plots were mowed $(2.5 \mathrm{~cm})$ or mowed and verticut (depth of $1.9 \mathrm{~cm}$ ) before herbicide application.

${ }^{\mathrm{w}}$ Control at 4, 8, and 12 WAIT were visually assessed while control at 17 WAIT was determined through grid counts (25 intersecting points).

${ }^{v}$ Means within a column followed by the same lowercase letter are not significantly different at $P \leq$ 0.05 according to Fisher's Protected LSD test.

${ }^{\mathrm{u}}$ The sequential application of trifloxysulfuron at $112 \mathrm{~g} \cdot \mathrm{ha}^{-1}$ a.i. exceeded the yearly maximum of $119 \mathrm{~g} \cdot \mathrm{ha}^{-1}$ a.i. compared with those same treatments following mowing alone. TFH (86\%) and TRI High CV $(85 \%)$ following mowing + verticutting resulted in the greatest long-term control 17 WAIT.

Deer Trail. Although control was minimal, mowing + verticutting resulted in $9 \%$ dallisgrass control whereas mowing alone provided no control (Table 4). Mowing + verticutting before herbicide application increased dallisgrass control 4 WAIT for the nontreated check, MSMA, and TRI Low CV compared with those same treatments following mowing alone. The greatest control 4 WAIT was observed in response to TRI High CV (81\%) and TFH (73\%) following mowing as well as MSMA (79\%), TRI High CV $(78 \%)$, and TFH (71\%) following mowing + verticutting.

Control increased for all treatments 8 WAIT (Table 4). The addition of mowing + verticutting further increased control to $21 \%$ for the nontreated check while mowing alone did not control dallisgrass. Dissimilarly, Henry et al. (2017) observed comparable lateral spread 2 MAIT of individual dallisgrass plants subjected to several verticutting events. However, research plots within this experiment were maintained at higher heights $(10.2 \mathrm{~cm})$ than those in our research $(2.5 \mathrm{~cm})$. Similar control $(89 \%$ to 93\%) was observed 8 WAIT in response to MSMA, TFH, and TRI High CV, regardless of cultural practice conducted before herbicide application.

The addition of mowing + verticutting resulted in a decrease in dallisgrass control in response to TRI High $\mathrm{CV}(80 \%)$ compared with TRI High CV following mowing alone (97\%) 12 WAIT (Table 4). Excellent control (89\% to $96 \%$ ) was observed in response to MSMA and TFH 12 WAIT, regardless of cultural practice conducted before application. This trend continued until the conclusion of the trial at 17 WAIT (Table 4). Increasing the carrier volume of trifloxysulfuron treatments from 407 to $1628 \mathrm{~L} \cdot \mathrm{ha}^{-1}$ increased dallisgrass control 17 WAIT by at least $53 \%$, regardless of cultural practice conducted before herbicide application; however, it is important to note that the sequential application of trifloxysulfuron at the high rate was higher than the yearly maximum of 119 $\mathrm{g} \cdot \mathrm{ha}^{-1}$ a.i. In a review of previous research, Knoche (1994) concluded that although efficacy was herbicide specific, decreasing carrier volumes below $100 \mathrm{~L} \cdot \mathrm{ha}^{-1}$ and increasing carrier volumes above $400 \mathrm{~L} \cdot \mathrm{ha}^{-1}$ led to a decrease in herbicide performance. Therefore, the greatest weed control was often observed when carrier volumes were between 100 and 400 $\mathrm{L} \cdot \mathrm{ha}^{-1}$. However, Henry et al. (2019) observed $90 \%$ to $92 \%$ dallisgrass control in response to trifloxysulfuron applied at $112 \mathrm{~g} \cdot \mathrm{ha}^{-1}$ a.i. at $1628 \mathrm{~L} \cdot \mathrm{ha}^{-1}$

Greenhouse experiments. Experimental run-by-treatment interactions for greenhouse trials were not significant for herbicide movement data $(\mathrm{F}=0.61, P=0.439)$. Therefore, data were pooled across experimental runs. A significant three-way interaction between 
cultivation practice, irrigation regime, and herbicide treatment $(\mathrm{F}=160.4, P<0.0001)$ were observed for herbicide movement (Table 5).

The annual ryegrass affected in the nontreated check may be due to seedling desiccation or seed loss near the exposed top of each soil column (Table 5). Irrigation following herbicide application to mowed plots did not increase herbicide presence within the soil profile, regardless of herbicide treatment. However, increasing the carrier volume and rate of trifloxysulfuron in mowed plots increased herbicide presence within the soil profile from 6.5 to $8.4 \mathrm{~mm}$ (nonirrigated) and 7.1 to $8.8 \mathrm{~mm}$ (irrigated). The presence of TFH within the soil profile in mowed plots was only 5.7-5.9 mm. Conversely, irrigation increase in herbicide presence within the soil profile, regardless of herbicide treatment (Table 5). Herbicide presence of TFH in mowing + verticutting treatments increased from 6.4 to $8.1 \mathrm{~mm}$ within the soil profile after irrigation was applied. The addition of irrigation to mowing + verticutting treatments resulted in an increase in herbicide presence of TRI Low CV of 6.7-8.5 mm and TRI High CV of 8.6-11.8 mm (Table 5).

The mobility of pesticides through the soil is primarily influenced by soil and pesticide dynamics (Bailey and White, 1970; Helling, 1970). Soil structure, particularly the extent that aggregates are grouped together, influences water infiltration rates and subsequently following herbicide application to mowing + verticutting treated plots resulted in an

herbicide sorption (Meite et al., 2018). The greater the macropore presence in the soil profile, the larger the influxes of water infiltration and the less time for herbicide sorption (Harper, 1994). The Koc value (organic water partitioning coefficient) of an herbicide, a chemical's affinity for the organic fraction of the soil, may further explain herbicide interactions within the soil profile (Harper, 1994). The higher the Koc value, the greater the affinity for adsorption to organic carbon in the soil. Trifloxysulfuron has a Koc value ranging from 29 to $574 \mathrm{~mL} \cdot \mathrm{g}^{-1}$ and water solubility of $5016 \mathrm{mg} \cdot \mathrm{L}^{-1}$ in a $\mathrm{pH}$ of 7.0 , indicating potential for movement within the soil (Shaner, 2014). In fact, Askew and Murphy (2009) and Matocha et al. (2006) reported trifloxysulfuron mobility in turfgrass and cotton (Gossypium hirsutum L.), respectively. Two of the components of TFH, foramsulfuron and halosulfuron, exhibit similar Koc values and water solubility as trifloxysulfuron, whereas the water solubility of thiencarbazone is only $436 \mathrm{mg} \cdot \mathrm{L}^{-1}$ at a $\mathrm{pH}$ of 7.0 (Shaner, 2014). This may limit TFH movement in the soil compared with trifloxysulfuron. Beckie and McKercher (1990) detected ethametsulfuron and chlorsulfuron at soil depths of 12,28 , and $32 \mathrm{~cm}$ in response to irrigation applications of $3.3,6.7$, and $10 \mathrm{~cm}$, respectively. Irrigation applications that were magnitudes greater than the amount of irrigation evaluated in our research as well as the use of an herbicide with high potential for movement (chlorsulfuron: Koc value $=40 \mathrm{~mL} \cdot \mathrm{g}^{-1}$ with water solubility of

Table 5. Influence of cultural practices and irrigation on the presence of herbicides within the profile of soil cores in the greenhouse in Athens, GA.

\begin{tabular}{|c|c|c|c|}
\hline Herbicide treatment $\mathrm{t}^{\mathrm{z}}$ & Cultural practice ${ }^{\mathrm{y}}$ & Irrigation $^{\mathrm{x}}$ & Herbicide movement $(\mathrm{mm})^{\mathrm{w}}$ \\
\hline Nontreated check & Mowing & No & $1.3 \mathrm{e}^{\mathrm{v}}$ \\
\hline Nontreated check & Mowing + verticutting & No & $1.3 \mathrm{e}$ \\
\hline Nontreated check & Mowing & Yes & $1.2 \mathrm{e}$ \\
\hline Nontreated check & Mowing + verticutting & Yes & $1.2 \mathrm{e}$ \\
\hline TFH & Mowing & No & $5.7 \mathrm{~d}$ \\
\hline TFH & Mowing + verticutting & No & $6.4 \mathrm{~cd}$ \\
\hline TFH & Mowing & Yes & $5.9 \mathrm{~d}$ \\
\hline TFH & Mowing + verticutting & Yes & $8.2 \mathrm{~b}$ \\
\hline TRI Low CV & Mowing & No & $6.5 \mathrm{~cd}$ \\
\hline TRI Low CV & Mowing + verticutting & No & $6.7 \mathrm{c}$ \\
\hline TRI Low CV & Mowing & Yes & $7.1 \mathrm{c}$ \\
\hline TRI Low CV & Mowing + verticutting & Yes & $8.5 \mathrm{~b}$ \\
\hline TRI High CV & Mowing & No & $8.4 \mathrm{~b}$ \\
\hline TRI High CV & Mowing + verticutting & No & $8.6 \mathrm{~b}$ \\
\hline TRI High CV & Mowing & Yes & $8.8 \mathrm{~b}$ \\
\hline TRI High CV & Mowing + verticutting & Yes & $11.8 \mathrm{a}$ \\
\hline $\operatorname{LSD}_{(0.05)}$ & - & - & 0.7 \\
\hline
\end{tabular}

${ }^{\mathrm{z}}$ TFH was applied at $137 \mathrm{~g} \cdot \mathrm{ha}^{-1}$ a.i.; trifloxysulfuron was applied at $28 \mathrm{~g} \cdot \mathrm{ha}^{-1}$ a.i. at $407 \mathrm{~L} \cdot \mathrm{ha}^{-1}$ (Low CV) and $112 \mathrm{~g} \cdot \mathrm{ha}^{-1}$ a.i. at $1628 \mathrm{~L} \cdot \mathrm{ha}^{-1}$ (High CV). TFH was applied with a methylated seed oil surfactant at $0.5 \%(\mathrm{v} / \mathrm{v})$ and ammonium sulfate at $1.7 \mathrm{~kg} \cdot \mathrm{ha}^{-1}$. Trifloxysulfuron was applied with a nonionic surfactant at $0.25 \%(\mathrm{v} / \mathrm{v})$.

${ }^{\mathrm{y}}$ Plots were mowed $(2.5 \mathrm{~cm})$ or mowed and verticut (depth of $\left.1.9 \mathrm{~cm}\right) 30 \mathrm{~min}$ before herbicide application.

xIrrigation $(6.4 \mathrm{~mm})$ was applied $24 \mathrm{~h}$ followed by $72 \mathrm{~h}$ after herbicide treatments for a total of 12.8 mm.

${ }^{\mathrm{w}}$ Herbicide movement was determined by monitoring the growth of annual ryegrass (Lolium multiflorum L.) planted along soil columns removed from the field following herbicide and irrigation treatments.

${ }^{\mathrm{v}}$ Means within a column followed by the same lowercase letter are not significantly different at $P \leq$ 0.05 according to Fisher's Protected LSD test.
$31,800 \mathrm{mg} \cdot \mathrm{L}^{-1}$ at a $\mathrm{pH}$ of 7.0 ) (Shaner, 2014) could explain the deeper herbicide presence in the soil profile observed by Beckie and McKercher (1990). Additionally, Starrett et al. (2000) recovered 3.2\%, 6.3\%, and $2.3 \%$ of applied 2,4-D, dicamba, and MCPP, respectively, following an irrigation regime that included a $0.6-\mathrm{cm}$ application immediately after herbicide applications, with 15 additional $0.6-\mathrm{cm}$ applications at $42-$ $\mathrm{h}$ intervals, providing a total of $2.5 \mathrm{~cm}$ of irrigation distributed evenly over a 7-day period.

Long-term dallisgrass control (17 WAIT) was enhanced in response to verticutting at the PH location. Greenhouse experiments confirmed that mowing and verticutting dallisgrass before treatment led to an increase in herbicide presence within the soil profile; therefore, potentially leading to an increase in root/rhizome absorption. Horst et al. (1996) reported that thatch layers retained twice the amount of pesticide following applications of chlorpyrifos, pendimethalin, isazofos, and metalaxyl compared with the $0-60-\mathrm{cm}$ soil profile located below. Thatch, a layer of living and decaying plant material, may decrease water infiltration or tightly bind herbicides (Dell et al., 1994; Gold et al., 1988). Therefore, verticutting the canopy removes thatch and exposes rhizomes, potentially wounding them in the process. Mowing alone and in combination with verticutting can cause significant plant wounding and the creation of reactive oxygen species (ROS) within dallisgrass (Asada, 1999; Del Río, 2015; Minibayeva et al., 2015). The accumulation of ROS can damage macromolecules such as lipids, proteins, and nucleic acids, ultimately leading to the reduction of photosynthesis and respiration (Asada, 1999; Kerchev et al., 2012). Consequently, lowered metabolic rates in response to mowing + verticutting could have contributed to an increase in dallisgrass control, regardless of herbicide. A nonmowed main factor was not incorporated into our research, but inclusion may have helped determine the additive effect of wounding compared with herbicides alone. However, inclusion of a nonmowed factor would have limited practicality since turfgrass is typically mowed on a regular basis. The increased presence and accumulation of herbicides in the root zone in response to mowing + verticutting and higher carrier volumes may have enhanced herbicide absorption of dallisgrass roots and rhizomes. Several researchers have documented enhanced activity of ALS-inhibiting herbicides through root absorption (Lycan and Hart, 2006; Sidhu et al., 2014; Williams et al., 2003).

Mowing + verticutting did not increase long-term control (17 WAIT) of dallisgrass at the DT site. Similar control was observed in response to herbicides applied after mowing alone and mowing + verticutting, except trifloxysulfuron at the high carrier volume, in which control was greater in response to mowing alone. Differences in previous cultural management may explain the variation in dallisgrass control between locations. The trial at DT was conducted on a golf course fairway maintained at $2.5 \mathrm{~cm}$, while the 
experiment at $\mathrm{PH}$ was located on a golf course rough managed at $5.1 \mathrm{~cm}$. Although both sites were mowed to $2.5 \mathrm{~cm}$ at trial initiation, dallisgrass at the $\mathrm{PH}$ location was previously growing with more canopy surface area and potentially more photosynthetic capability. Henry et al. (2007a) observed similar reductions in dallisgrass rhizome fresh weight in response to mowing heights of 1.3, 5.2 , and $7.6 \mathrm{~cm}$, but Watson and Ward (1970) reported less total available carbohydrates in dallisgrass maintained at $2.5 \mathrm{~cm}$ compared with $7.5 \mathrm{~cm}$. Thus, less carbohydrates may have been available for dallisgrass plants to recover from herbicide and mechanical damage at DT compared with $\mathrm{PH}$, leading to greater control, regardless of cultural treatment. Secondly, the reduction in aboveground dallisgrass biomass at the $\mathrm{PH}$ site may have decreased herbicide absorption through the leaves compared with the DT location. Future research should further examine mowing + verticutting timing and frequency in addition to irrigation practices following herbicide application in the field to maximize long-term dallisgrass control.

\section{Literature Cited}

Asada, K. 1999. The water-water cycle in chloroplasts: Scavenging of active oxygen and dissipation of excess photons. Annu. Rev. Plant Physiol. Plant Mol. Biol. 50:601-639.

Askew, S.D. and T.R. Murphy. 2009. Relative mobility of transition assisting herbicides. Int. Turfgrass Soc. Res. J. 11:1153-1158.

Bailey, G.W. and J.L. White. 1970. Factors influencing the adsorption, desorption, and movement of pesticides in soil. Residue Rev. 32:29-92, doi:https://doi.org/10.1007/978-1-4615-8464-3_4.

Beckie, H.J. and R.B. McKercher. 1990. Mobility of two sulfonylurea herbicides in soil. J. Agr. Food Chem. 38:310-315.

Bowley, S.R. 2008. A hitchhiker's guide to statistics in Plant Biology. 2nd ed. Any Old Subject Books, Guelph, ON, Canada.

Brosnan, J.T., G.K. Breeden, M.T. Elmore, and J.M. Zidek. 2010. Early and late postemergence control of dallisgrass in tall fescue. Appl. Turfgrass Sci. 7:1-10, doi:https://doi.org/ 10.1094/ATS-2010-0312-02-RS.

Bryson, C.T. and M.S. DeFelice (eds.). 2009. Weeds of the South. University of Georgia Press, Athens, GA.

Bryson, C.T. and G.D. Wills. 1985. Susceptibility of bermudagrass (Cynodon dactylon) biotypes to several herbicides. Weed Sci. 33:848-852.

Currier, H.B. and C.D. Dybing. 1959. Foliar penetration of herbicides-Review and present status. Weeds 7:195-213.

Davis, H.E., R.S. Fawcett, and R.G. Harvey. 1978. Effect of fall frost on the activity of glyphosate on alfalfa (Medicago sativa) and quackgrass (Agropyron repens). Weed Sci. 26:41-45.

Dell, C.J., J.S. Throssell, M. Bischoff, and R.F. Turco. 1994. Estimation of sorption coefficients for fungicides in soil and turfgrass thatch. $\mathrm{J}$. Environ. Qual. 23:92-96.

Del Río, L.A. 2015. ROS and RNS in plant physiology: An overview. J. Expt. Bot. 66:2827-2837, https://doi.org/10.1093/jxb/erv099.

Elmore, M.T., J.T. Brosnan, T.C. Mueller, B.J. Horvath, D.A. Kopsell, and G.K. Breeden. 2013. Seasonal application timings affect dallisgrass (Paspalum dilatatum) control in tall fescue. Weed Technol. 27:557-564, https://doi. org/10.1614/WT-D-13-00007.1.

Federer, W.T. and M.P. Meredith. 1992. Covariance analysis for split-plot and split-block designs. Amer. Stat. 46:155-162.

Gold, A.J., T.G. Morton, W.M. Sullivan, and J. McClory. 1988. Leaching of 2,4-D and dicamba from home lawns. Water Air Soil Pollut. 37:121-129.

Hall, D.W., L.B. McCarty, and T.R. Murphy. 1994. Weed taxonomy, p. 9-10. In: A.J. Turgeon (ed.). Turf weeds and their control. American Society of Agronomy, Madison, WI.

Harper, S.S. 1994. Sorption-desorption and herbicide behavior in soil. Rev. Weed Sci. 6:207-221.

Heath, M.E., D.S. Metcalfe, and R.F. Barnes 1973. Forages: The science of grassland agriculture. 2nd ed. Iowa State University Press, Ames, IA.

Helling, C.S. 1970. Movement of S-triazine herbicides in soils. Residue Rev. 32:175-210.

Henry, G., J. Burton, R. Richardson, and F. Yelverton. 2008. Absorption and translocation of foramsulfuron in dallisgrass (Paspalum dilatatum) following preapplication of MSMA. Weed Sci. 56:785-788, https://doi.org/10.1614/ WS-08-035.1.

Henry, G.M., M.G. Burton, and F.H. Yelverton. 2007a. Effect of mowing on lateral spread and rhizome growth of troublesome Paspalum species. Weed Sci. 55:486-490, https://doi.org/ 10.1614/WS-07-030.1.

Henry, G.M., R.A. Grubbs, and C.R. Johnston. 2017. Response of bahiagrass and dallisgrass to verticutting frequency. Proc. Southern Weed Sci. Soc. 70:52.

Henry, G.M., K.A. Tucker, J.T. Brosnan, and G. Breeden. 2019. Spray volume and application rate of trifloxysulfuron affects long-term dallisgrass control. Proc. Southern Weed Sci. Soc. 72:27.

Henry, G.M., F.H. Yelverton, and M.G. Burton 2007b. Dallisgrass (Paspalum dilatatum) control with foramsulfuron in bermudagrass turf Weed Technol. 21:759-762, https://doi.org/ 10.1614/WT-06-163.1.

Henry, G.M., F.H. Yelverton, and M.G. Burton. 2009. Asymmetric responses of Paspalum species to a soil moisture gradient. Crop Sci. 49:1473-1480, https://doi.org/10.2135/cropsci2008.08.0506.

Holt, E.C. and J.C. McDaniel. 1963. Influence of clipping on yield, regrowth, and root development of dallisgrass, Paspalum dilatatum, and kleingrass, Panicum coloratum L. Agron. J. 55:561-564

Horst, G.L., P.J. Shea, N. Christians, D.R. Miller, C. Stuefer-Powell, and S.K. Starrett. 1996. Pesticide dissipation under golf course fairway conditions. Crop Sci. 36:362-370.

Johnson, B.J. 1992. Common bermudagrass (Cynodon dactylon) suppression in Zoysia spp With herbicides. Weed Technol. 6:813-819.

Johnston, C.R. and G.M. Henry. 2016. Dallisgrass (Paspalum dilatatum) control with thiencarbazonemethyl, foramsulfuron, and halosulfuron-methyl in bermudagrass turf. HortScience 51:754-756, https://doi.org/10.21273/HORTSCI.51.6.754

Kerchev, P.I., B. Fenton, C.H. Foyer, and R.D. Hancock. 2012. Plant responses to insect herbivory: Interactions between photosynthesis, reactive oxygen species and hormonal signaling pathways. Plant Cell Environ. 35:441-453, https:// doi.org/10.1111/j.1365-3040.2011.02399.x.

Knoche, M. 1994. Effect of droplet size and carrier volume on performance of foliage-applied herbicides. Crop Prot. 13:163-178, https://doi.org/ 10.1016/0261-2194(94)90075-2.
Loreti, J. and M. Oesterheld. 1996. Intraspecific variation in the resistance to flooding and drought in populations of Paspalum dilatatum from different topographic positions. Oecologia 108:279-284.

Lycan, D.W. and S.E. Hart. 2006. Foliar and root absorption and translocation of bispyribacsodium in cool-season turfgrass. Weed Technol. 20:1015-1022.

Matocha, M.A., L.J. Krutz, S.A. Senseman, C.H. Koger, K.N. Reddy, and E.W. Palmer. 2006. Spray carrier $\mathrm{pH}$ effect on absorption and translocation of trifloxysulfuron in Palmer amaranth (Amaranthus palmeri) and Texasweed (Caperonia palustris). Weed Sci. 54:969-973, https://doi.org/10.1614/WS-06-029.1.

McCarty, L.B., L.C. Miller, and D.L. Colvin. 1991. Bermudagrass (Cynodon spp.) cultivar response to diclofop, MSMA and metribuzin. Weed Technol. 5:27-32.

McCarty, L.B. 2008. Color atlas of turfgrass weeds. John Wiley \& Sons, Hoboken, NJ.

McElroy, J.S. and G.K. Breeden. 2006. Triclopyr safens the use of fluazifop and fenoxaprop on zoysiagrass while maintaining bermudagrass suppression. Appl. Turf Sci. 3(1): https://doi. org/10.1094/ATS-2006-0502-01-RS

Meite, F., P. Alvarez-Zaldívar, A. Crochet, C. Wiegert, S. Payraudeau, and G. Imfeld. 2018. Impact of rainfall patterns and frequency on the export of pesticides and heavy metals from agricultural soils. Sci. Total Environ. 616:500-509, https:// doi.org/10.1016/ j.scitotenv.2017.10.297.

Minibayeva, F., R.P. Beckett, and I. Kranner. 2015. Roles of apoplastic peroxidases in plant response to wounding. Phytochemistry 112:122-129, https://doi.org/10.1016/j.phytochem.2014.06.008.

Peppers, J.M., C.G. Gonçalves, and J.S. McElroy. 2020. Rate response of select grass weeds to pinoxaden. Weed Technol. 34:818-823, https:// doi.org/10.1017/wet.2020.65.

Richardson, M.D., D.E. Karcher, and L.C. Purcell. 2001. Quantifying turfgrass cover using digital image analysis. Crop Sci. 41:1884-1888.

Richardson, M.D., J.T. Brosnan, J.H. McCalla, and G.K. Breeden. 2020. Fraise mowing can improve herbicidal control of bermudagrass. Agron. J., https://doi.org/10.1002/agj2.20411.

Rubio, G., G. Casasola, and R.S. Lavado. 1995. Adaptations and biomass production of two grasses in response to waterlogging and soil nutrient enrichment. Oecologia 102:102-105.

Shaner, D.L. 2014. Herbicide handbook. 10th ed. Weed Science Society of America, Lawrence, KS.

Shaw, D.R., W.H. Morris, E.P. Webster, and D.B. Smith. 2000. Effects of spray volume and droplet size on herbicide deposition and common cocklebur (Xanthium strumarium) control. Weed Technol. 14:321-326.

Sidhu, S.S., J. Yu, and P.E. McCullough. 2014. Nicosulfuron absorption, translocation, and metabolism in annual bluegrass and four turfgrass species. Weed Sci. 62:433-440, https:// doi.org/10.1614/WS-D-13-00182.1.

Smith, B.E., D.G. Shilling, W.T. Haller, and G.E. Macdonald. 1993. Factors influencing the efficacy of glyphosate on torpedograss (Panicum repens L.). J. Aquat. Plant Mgt. 31:199-202.

Smith, J.E., A.W. Cole, and V.H. Watson. 1974 Selective smutgrass control and forage quality response in bermudagrass-dallisgrass pastures. Agron. J. 66:424-426.

Starrett, S.K., N.E. Christians, and T. Al Austin. 2000. Movement of herbicides under two irrigation regimes applied to turfgrass. Adv 
Environ. Res. 4:169-176, https://doi.org/ 10.1016/S1093-0191(00)00020-4.

Striker, G.G., P. Insausti, A.A. Grimoldi, and R.J.C. Leon. 2006. Root strength and trampling tolerance in the grass Paspalum dilatatum and the dicot Lotus glaber in flooded soil. Funct. Ecol. 20:4-10, https://doi.org/10.1111/ j.1365-2435.2006.01075.x.

Turgeon, A.J. 2011. Turfgrass management, 9th ed. Prentice Hall, Hoboken, NJ.
U.S. Environmental Protection Agency. 2009. Agreement in principle to implement the organic arsenicals Reregistration Eligibility Decision (RED). U.S. Environmental Protection Agency, Washington, DC. 4 Nov. 2020. <https:/www. regulations.gov/document/EPA-HQ-OPP-20090191-0004>.

Venuto, B.C., B.L. Burson, and M.A. Hussey. 2003. Forage yield, nutritive value, and grazing tolerance of dallisgrass biotypes. Crop Sci. 43:295-301.
Watson, V.H. and C.Y. Ward. 1970. Influence of intact tillers and height of cut on regrowth and carbohydrate reserves of dallisgrass (Paspalum dilatatum Poir.). Crop Sci. 10:474-476.

Williams, W., G. Wehtje, and R.H. Walker. 2003. CGA-362622: Soil behavior and foliar versus root absorption by torpedograss (Panicum repens). Weed Technol. $17: 366-372$. 